\title{
The Application of Numbered Head Together Model to Enhance Students' Activity and Learning Outcome on Two-Dimensional Figures Material
}

\author{
Nur Afiyah Rohmayati \\ Elementary School Teacher Education \\ Universitas Negeri Malang, Indonesia \\ nurafiyah387@gmail.com
}

\author{
Sumanto \\ Elementary School Teacher Education \\ Universitas Negeri Malang, Indonesia \\ sumanto.fip@um.ac.id
}

\author{
I Made Suardana \\ Elementary School Teacher Education \\ Universitas Negeri Malang, Indonesia \\ i.made.suardana.fip@um.ac.id
}

\begin{abstract}
This study aims to improve the students' activeness and learning outcomes. The design of this study is classroom action research consisting of two cycles. The results obtained in this study are teacher activity in the cycle I which is increasing $76 \%$ and, in the cycle II, which also is increasing $87.5 \%$. Student activity which was $72.42 \%$ in the cycle I improved to $89.42 \%$ in the cycle II. In the cycle I the average score of student learning achievement is 70.84 with $50 \%$ classical completeness, while in the cycle II is 87.16 with $77.78 \%$ classical completeness.
\end{abstract}

Keywords: activeness, learning achievement, numbered head together model

\section{INTRODUCTION}

Mathematics is one of the subjects that need to be learned by all students starting from elementary school to equip students with "the ability to think logically, analytically, systematically, critically, and creatively, and have the skill to cooperate" (BSNP, 2006). The mindset is something that students need to have as a provision in their daily lives. The application of mathematics in everyday life will be able to help in various aspects of life. In reality, sadly, students, especially elementary school students (SD), often consider mathematics as a difficult, unpleasant, and frightening subject because mathematical studies are considered abstract so that most of the students find it difficult in learning mathematical material.

Geometry is one of aspects which are within the coverage of mathematics which is considered difficult for students to understand especially in elementary schools. Walle (2001) urges that studying geometry is important because geometry is very closely related to everyday life and has an important role in studying other branches of mathematics. The topic of geometry materials taught to fourth graders are the circumference and area of twodimensional figures. Topic of two-dimensional figures had previously been transmitted in the grade III, but most students still find it hard to learn the material. This is caused by the lack of students' understanding of mathematical concepts. For example, if students fail to understand the concept of two-dimensional figures, students will have difficulties in solving advanced problems such as circumference and the area of the figures. In line with that, Waskitoningtyas (2016) believes that the inability of learning is induced by the students' failure to understand basic knowledge and correlate new knowledge to the old one so it leads to a material incomprehension or obscurity. Besides, sometimes teachers are also too monotonous in delivering abstract mathematical material.

Abstract mathematics material makes it difficult for students to comprehend it. The concept understanding is about how much students want to accept, acquire, and comprehend the material delivered by the teacher to students. Teachers are required to be able to teach comprehendible mathematical materials. In the process of teaching two-dimensional figure, teachers have to develop the students' creativity so that students may improve their thinking skills and "ability to construct new knowledge" as an effort to improve good mastery of mathematical material (Nawawi, Mahanani, \& Putra, 2018; Susanto, 2016).

Based on the researchers' experience at SDN Bumiayu 1 during their field study period in mathematics class of the grade IV, students lacked enthusiasm in learning topic of fractions which was proven by students' learning activities when the teacher explained it in front of the class where 9 students were busy with themselves, 4 students were daydreaming, 2 students were sleeping, and 3 students were observed busy taking notes but after further observation it turned out that what the students recorded was not in accordance with what was explained by the teacher. Furthermore, when they were working on the practice questions given, they did it long in the sense of time spent, even some of the students were caught imitating the work of their friends. This is caused by the 
lack of teacher's variation in teaching mathematics. The lecture method whom teacher relying too much on provoked students into boredom and the lack of enthusiasm. Besides, too many numbers of students in a class, 36 students, undermines the classroom management.

The learning difficulties experienced by students lead to poor learning achievements which are mostly under the KKM (Minimal Completeness Criteria). Based on the learning achievement retrieved during the preliminary study on February 19th, 2019, most the learning achievement of IV grade students of SDN Bumiayu 1 failed to surpass the determined by KKM which is 75 . Only 9 out of 36 students $(25 \%)$ succeeded to meet the KKM, while the other 27 students or the rest $75 \%$ of the students did not.

In order to solve the problem, the teaching activity should be improved where the teacher may employ the Numbered Head Together model. This NHT model is considered suitable to improve students' learning activities and achievements on mathematics subjects. This is backed by Ardiani (2014) who argues that the application of the Numbered Head Together model can improve students' activeness and learning outcomes because in this model students are put in a very dominant position during the learning process. There also is cooperation in groups with the main characteristics of numbering so that all students strive to understand every taught material and are responsible for the number of their respective heads.

Based on the aforementioned description, the purpose of the study is describing (1) the implementation of Numbered Head Together model in conducting mathematics teaching in the topic of two-dimensional figures in grade IV of SDN Bumiayu 1 Malang, (2) the improvement of students' mathematics learning activities on two-dimensional figures topic by using the Numbered Head Together model in the fourth grade of SDN Bumiayu 1 Malang, and (3) the improvement of students' mathematics learning achievement on two-dimensional figures topic by using the Numbered Head Together model in the fourth grade of SDN Bumiayu 1 Malang.

\section{METHOD}

The study employs classroom action research method with a collaborative research model. The researcher collaborated with the fourth-grade teacher of SDN Bumiayu 1. This study utilizes the cycle model of Kemis \& Taggart MC designed to be carried out in two cycles. Each cycle consists of planning, implementation, observation, and reflection. This study was conducted in the fourth grade of SDN Bumiayu 1 in the academic year of 2018/2019 which consists of 36 students. During the study, researchers acted as teachers while the grade IV teachers acted as the observer. The data of the study covers the data about the application of the Numbered Head Together model, the observation results on student activeness, and data on students' learning outcomes. The utilized data collection techniques were: (1) observation, (2) tests, (3) interviews, and (4) documentation. The operated data analysis in the study was descriptive qualitative and quantitative descriptive data analyses. In the qualitative descriptive data analysis, data analysis is displayed in form of a description of data explanation in form of sentences or words, while the descriptive quantitative data analysis was a data presentation in which are in form of numbers to facilitate final conclusion.

\section{RESULTS}

\section{The Description of the Cycle I}

The implementation of mathematics teaching by using the Numbered Head Together model in the first meeting of the first cycle lead to the score of 75 with the $75 \%$ value, while for the implementation of the second meeting came to improvement into the score of 77 with $77 \%$ value. During the first cycle there were several findings during the ongoing learning activities including that (1) the teacher lacked of classroom management mastery so that the class was observed to be noisy and ignorant when the teacher was explaining the material, (2) during the process of group division, the teacher asked the group representatives to come forward to take the head number and name of the group so that the representatives scrambled for the number where the teacher is should be the one who goes around the class to distribute the head number to each group, (3) there was a syntax of the Numbered Head Together which had not been implemented by the teacher, the conclusion, (4) the teacher focused only on the front seat students so that the back seat students were busy on their own.

The activeness of grade IV students of SDN Bumiayu 1 Malang during the application of the Numbered Head Together model of the first cycle experienced an improvement on the second meeting compared to on the first one. In the first meeting of the first cycle, the obtained score was 32 with a value of $61.54 \%$, while in the second meeting, the achieved score was 40 with a value of $83.3 \%$. During the first cycle there were several findings during the learning activities, namely, that (1) the students were not fully active in question and answer activities and group discussions, (2) students were seemed unconfident as their response when the teacher appointed them to come forward where the appointed students were afraid of going to the front of the class worrying of possibly wrong answer, (3) some students were not comfortable to wear the number above their head and scribbled the head number, (4) when the teacher were explaining, some students were busy with themselves and did not pay attention to the teacher's explanation.

The learning achievement of grade IV students of SDN Bumaiyu 1 Malang in learning mathematics by implementing the Numbered Head Together model experienced an increase from the first meeting to the second meeting. It is proven by the average score of the students which is from 63.75 to 77.92 . The number of students who surpassed the KKM in the first meeting of first cycle was 12 students or $33.33 \%$, while on the second meeting there were successful 24 students or $66.67 \%$. While students who have not completed their learning outcomes at the first meeting were 24 students with a percentage of $66.67 \%$ to 12 students with a percentage of $33.33 \%$ at the second meeting. This is caused by some students did not understand about how to 
compute the circumference and the area of twodimensional figures if the question is in the form of a description text. Besides the numbers contained in the question were too many.

\section{The Description of the Cycle II}

The implementation of mathematics learning applying the Numbered Head Together model in the first meeting of the first cycle come to the score of 84 with the value of $84 \%$, while on the second meeting the students got 91 with $91 \%$ value. During the second cycle there were several findings during the learning activities, such as that: (1) the teacher was able to control the class so that by the classroom management the students could focus on the teacher, (2) during the group division process, the teacher who went around made sure all the head numbers were worn by all students, (3) the teacher had carried out all the syntax of the Numbered Head Together model without missing anything, and (4) although the teacher went around not only in the front seat but also the back seat, there are still some students who are busy with themselves so that the teacher had to ask them individually related to the learning material that had been conducted.

The activity of the fourth-grade students of SDN Bumiayu 1 Malang during the application of the Numbered Head Together model which was carried out in the first cycle increased from the first meeting to the second meeting. In the first meeting of the second cycle, students' score is 46 with a value of $88.46 \%$. Then it increased in the second meeting by the score of 47 with the value of $90.38 \%$.

During the first cycle there were several findings during the process of learning activities including that: (1) students were active in question and answer activities and group discussions, (2) students had begun to be confident which can be proven by many students who raised their hands without being appointed by the teacher to give responses and questions, (3) some students did not like to wear head numbers above their heads but like to scribble on those head numbers, (4) when the teacher explained, students focused on the teacher's explanation.

Learning achievement of the students in the grade IV of SDN Bumaiyu 1 Malang in learning mathematics by applying the Numbered Head Together model which was carried out in the second cycle experienced an increase from the first meeting to the second one. Students' average score improved from the first (84.31) to the second cycle (90). The number of success students to surpass the KKM at the first meeting was 26 students with $72.22 \%$ percentage.

Furthermore, 30 students were succeeding the KKM with $83.33 \%$ percentage at the second meeting. Conversely, failing students who have not completed the KKM in the first meeting were 10 students or $27.78 \%$, while on the second meeting was 6 students or $16.66 \%$. This may be caused by the test items which were in form of description texts had been simplified by adjusting to the students' understanding and separating the material of circumference and the area of two-dimensional figure. For the circumference topic was put in the first meeting of the second cycle, while the material area was put in the second meeting of cycle II to optimize students' understanding to the topics better.

\section{DISCUSSIONS}

1. The Application of Numbered Head Together Model in Conducting Mathematics Teaching on the Topic of Two-Dimensional Figures

Data of the Numbered Head Together model application is in form of teacher activity data in teaching carried out in two cycles: cycle I and cycle II. Each cycle had 2 meetings with time allocation of $3 \times 35$ minutes each. The learning activity on the topics of area and circumference was carried out by complying the guidance to conduct Numbered Head Together model. According to Trianto (2010) there are four steps to satisfy including: (1) numbering: the teacher divides students into groups of 3 to 5 students and gives numbers to each group members so that each student has a number between 1-5, (2) questioning: the teacher asks a question to the groups, (3) heads together: students work together to find the answer and ensure that all the group members know the answer, (4) answering: the teacher pick a random number from each group whose owner then raise her/his hand and give an answer to the class.

Based on the description of the cycle I and cycle II data carried out by the teacher in accordance with the steps of the Numbered Head Together learning model, the application of Numbered Head Together learning model generally went well. This was indicated by an increase of teacher activity, where the score in the first meeting of the first cycle was $75 \%$ included as good category while in the score of the second meeting of the first cycle was $77 \%$ which also is included in the good category. Then in the meeting 1 of the second cycle, the score was $84 \%$ or in good category which experience another improvement to the level of $91 \%$ or in a very good category on the second meeting of the second cycle. The increased teacher activity in implementing the Numbered Head Together learning model is depicted in the following Figure 1.

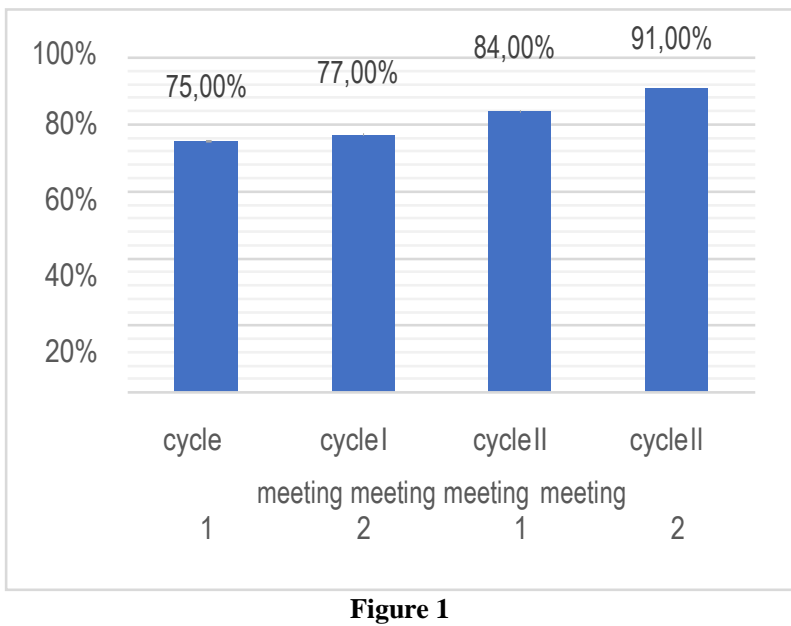

The Increasing Teacher Activity in Implementing the NHT Model

In Figure 1 above, teacher activity in learning appears to increase at each meeting. The increasing activity is inseparable from the role of the teacher, namely as the facilitator, innovator, and motivator so that the learning proses turns to be more meaningful. 
2. The Increasing Students' Activeness in Applying the Numbered Head Together Model on the Topic of Two-Dimensional Figure

The observation data of student activeness were obtained from teaching activities in 2 cycles with 2 meetings each. The implementation of students' activeness was only observed by the classroom teacher as the observer. During the learning activities, learning activeness are required by students. This is in line with the opinion of Sardiman (2014) which suggests that activeness is a principle or basis that is very important in teaching and learning interactions, without activeness the learning process is not possible to undergo in the good fashion.

The implementation of student activeness in learning by applying the Numbered Head Together model from each meeting had increased. The increase was observable in the success percentage of student activeness in the first meeting of the first cycle which was in the level of $61.54 \%$ or moderate category while in in the second meeting of the first cycle the score was $83.3 \%$ or in good category. In the first meeting of the second cycle the score was $88.46 \%$ or in good category and experienced an increase in the first meeting of the second cycle to the level of $90.38 \%$ or in good category. The percentage increase is summarized in the following Figure 2.

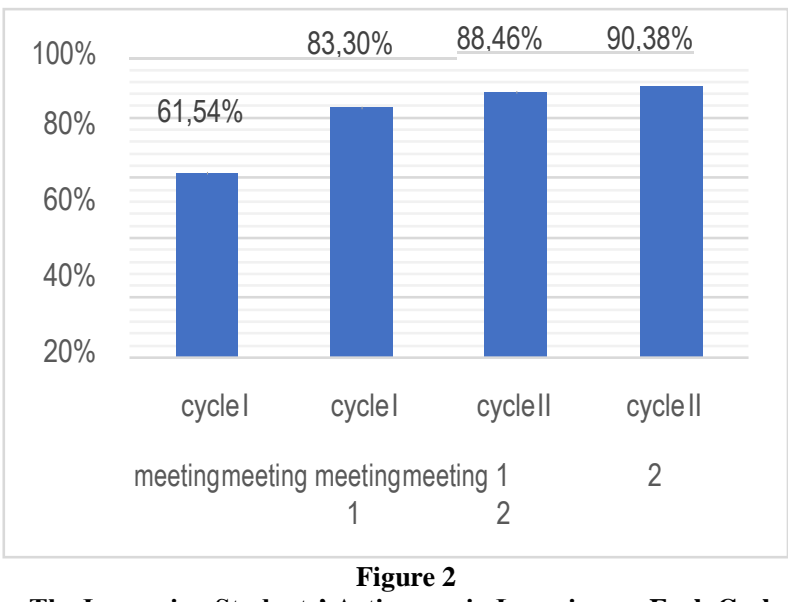

The Increasing Students' Activeness in Learning on Each Cycle

Based on Figure 2 above, the activeness of the fourth-grade students in SDN Bumiayu 1 Malang experienced an increase during the carried-out learning process. Initially, in the first meeting of the first cycle and the second meeting of the first cycle, the students were uncontrollably noisy during the process of group division, LKK (Student Worksheet) distribution, and group discussion. Besides, the students were also lack of confidence to raise their hands during question and answer session because they like to ask their friends better. Furthermore, an increase occurred in both meetings of the second cycle. The increase is visible when students began to be cooperative and no longer hesitate to raise hands during question and answer session (Rachmah, Sunyoto, \& Sutansi, 2017). They also seemed to be active in presentations, group work, and take part in the learning process in accordance to the guidance provided by the Numbered Head Together model.

Based on the statement above, the implementation of the action in cycle I was not optimal in applying the Numbered Head Together model. There was still a syntax that was not implemented in the second meeting of the first cycle, which was a conclusion. Meanwhile, on the second cycle, the learning activity was sequentially carried out according to all the syntax of Numbered Head Together model suggest.

\section{Improving Mathematics Learning Achievements in the Topic of Two-Dimensional Figure by Employing Numbered Head Together Models}

Based on observational data, it can conclude that the application of the Numbered Head Together model in teaching mathematics in the topic of two-dimensional figure can improve students' learning achievement. Improved learning achievement is observable from students' learning achievement through assessment on the evaluation sheet which was done at the end of each lesson. The assessment was carried out to measure the success of students in comprehending the taught material. This is in line with Hamalik (2009) who believes that learning achievement as the achieved level of mastery by students in attending the teaching process in accordance with the determined goals of education.

Regarding on students' learning outcomes in the first meeting of the first cycle, there were 2 students $(5.56 \%)$ who achieved the grades in very good category, 10 students $(27.78 \%)$ obtained good grades, 16 students $(44.44 \%)$ obtained grades with moderate category, and 8 students $(22.22 \%)$ scored with poor category. Meanwhile in the second meeting of the first cycle, 15 students $(41.67 \%)$ achieved score of the very good category, 9 students $(25 \%)$ obtained score of the good category, 5 students $(13.89 \%)$ obtained grades of moderate category, and 7 students (19.44\%) obtained score of poor categories. This means that students' learning achievement from the first meeting of the first cycle had increased in the second meeting of the first cycle. The improvement in learning achievement are summarized in the following Figure 3.

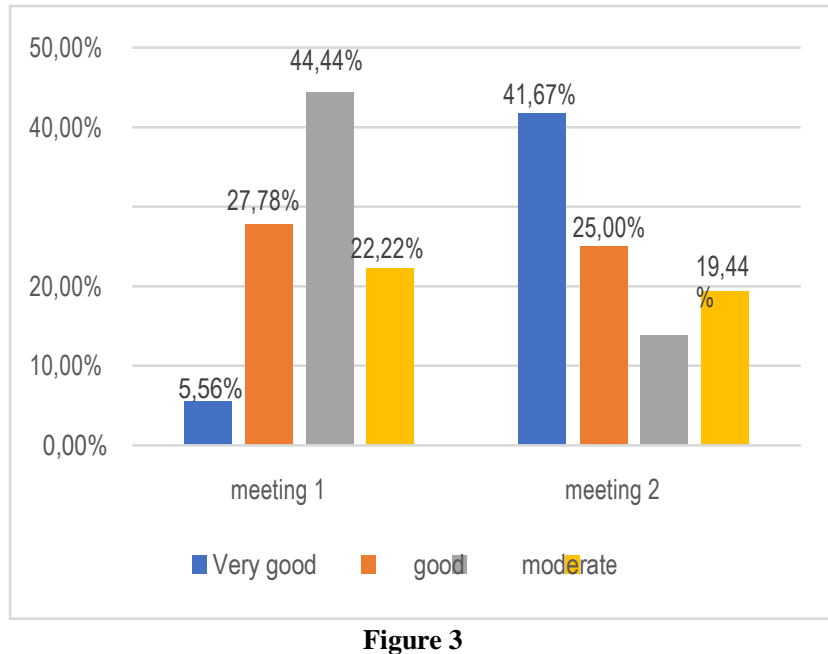

The Increasing of Mathematics Learning Achievement on the First Cycle 
In the first meeting of the second cycle, there were 14 students $(38.89 \%)$ who achieved score of very good category, 12 students (33.33\%) obtained good score, 9 students $(25 \%)$ obtained grades with moderate category, and 1 student $(2.78 \%)$ scored in the poor category. Further, on the second meeting of the second cycle, there were 22 students $(61.11 \%)$ achieved scores of very good categories, 9 students (25\%) obtained good grades, 2 students $(5.56 \%)$ obtained score of moderate categories, and 3 students $(8.33 \%)$ obtained score of poor categories. This indicates that students' learning achievement from the first meeting of the second cycle increased on the second meeting of the second cycle. The improvement in students' learning achievement is depicted in the following Figure 4.

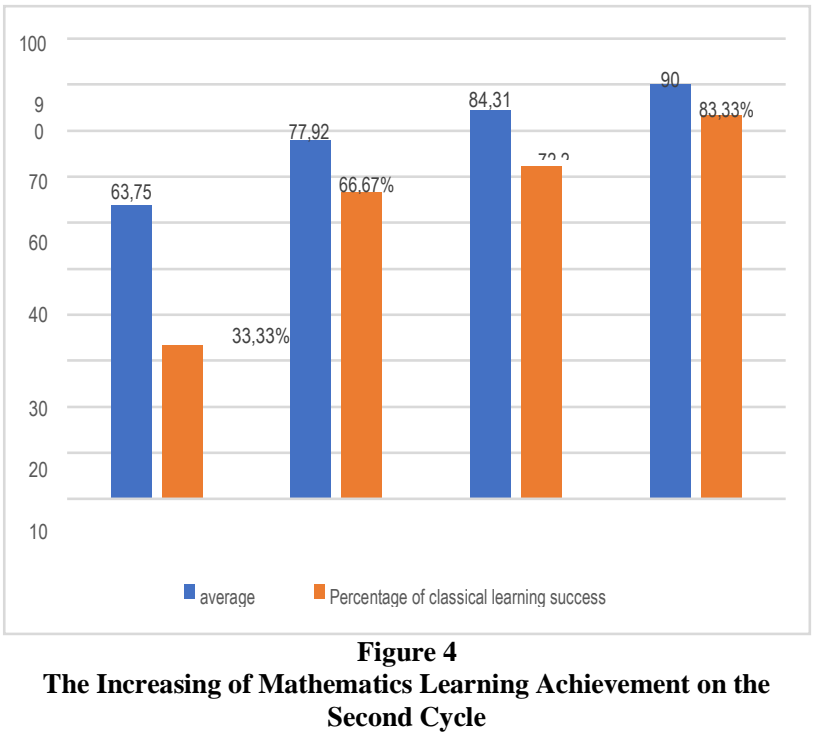

Based on students' learning achievement in the first meeting of the first cycle, the average students' learning score were 63.75 with $33.33 \%$ percentage of classical learning completeness with poor category. Then in the second meeting of first cycle, there was an increase of the score average of students' learning achievement to 77.92 with $66.67 \%$ percentage of classical learning completeness in moderate category. Actually, an increase occurred in the first cycle but there were still many students whose scores are far from KKM. So, the teacher had to conduct the second cycle.

The average score of students' learning achievement in the first meeting of the second cycle was 84.31 with $72.22 \%$ percentage of classical learning completeness in moderate category which then experienced an increase again in the second meeting of the second cycle where the average score of the students' learning achievement was 90 with $83.33 \%$ percentage of classical learning completeness of the good category. This is in accordance with previous research conducted by Fitriyana (2018) and Cahyono (2015) which came to the result that the Numbered Head Together learning model can improve students' learning activeness and achievement. The percentage of success in increasing students' score is illustrated Figure 5.

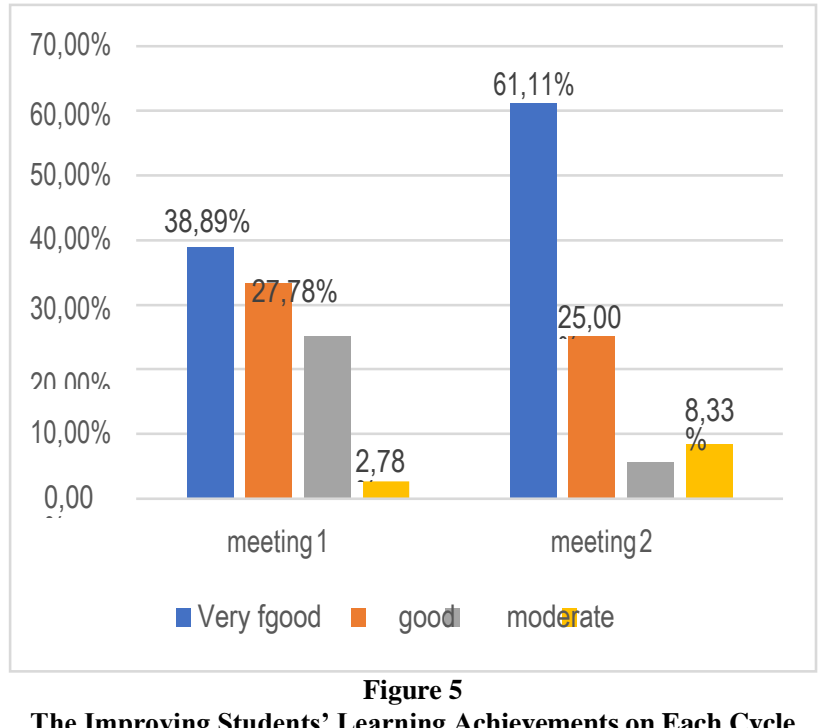

\section{CONCLUSIONS}

The implementation of the Numbered Head Together model on the topic of two-dimensional figure was successfully carried out in SDN Bumiayu 1 Malang. This success is pointed out by the increase of teacher activeness during the implementation of the Numbered Head Together model in the first meeting of the first cycle from $75 \%$ success percentage to $77 \%$ in the second meeting of the first cycle. In the first meeting of the second cycle the success percentage was $84 \%$ which then increased to $91 \%$ in the second meeting of the second cycle.

Students' learning activeness with the Numbered Head Together model on the topic of two-dimensional figure had also increased. In the first meeting of the first cycle, students' learning activeness achieved a success percentage in the level of $61.54 \%$ which then increased in the second meeting with $83.3 \%$ success percentage. In the first meeting of the second cycle the percentage of success was $88.46 \%$ which then also increased to $90.38 \%$ in the second meeting of the second cycle.

Students' learning achievement with the Numbered Head Together model on the topic of twodimensional figure had also experience an increase. This inferred from the results of the student learning average in the first meeting of the first cycle which was 63.75 with $33.33 \%$ percentage of classical learning success. It then increased in the second meeting of the first cycle where the students' learning average of 77.92 with $66.67 \%$ percentage of learning success classical. In the first meeting of the second cycle the student learning average was 84 with $72.22 \%$ as the percentage of classical learning success. It then raised again in the second meeting of the second cycle where the student learning average came to the level of 90 with $83.33 \%$ percentage of classical learning success.

\section{REFERENCES}

[1] Ahmad, S. 2016. Teori Belajar Pembelajaran di Sekolah Dasar. Jakarta: Prenada Media Group.

[2] Ardiani, A. 2014. Penerapan Model Pembelajaran Kooperatif Tipe Numbered Heads Together (NHT) Pada Materi Bangun Datar Segi Empat Untuk Meningkatkan 
Aktivitas, Respon Dan Prestai Belajar Siswa Kelas VII-B MTs Negeri Sampung Ponorogo Tahun Pelajaran 2013/2014. Retrieved 21 July 2019, from http://eprints.umpo.ac.id.

[3] BSNP. 2006. Permendiknas RI No. 22 Tahun 2006 tentang Standar Isi untuk Satuan Pendidikan Dasar dan Menengah. Jakarta.

[4] Fitriyana, D. R. 2017. Penerapan Model Numbered Head Together (NHT) Untuk Meningkatkan Aktivitas dan Hasil Belajar Siswa Kelas III Tema 6 Subtema 2 SDN Bunulrejo 5 Kecamatan Blimbing Kota Malang. Malang: FIP UM.

[5] Hamalik, O. 2009. Proses Belajar Mengajar. Jakarta: Bumi Aksara.

[6] Nawawi, I., Mahanani, P., \& Putra, A. P. (2018, September). A Learning Journal to Improve the Ability of Students in Critical Thinking BT - 1st International Conference on Early Childhood and Primary Education
(ECPE 2018). Retrieved 21 July 2019, from https://doi.org/https://doi.org/10.2991/ecpe-18.2018.20.

[7] Sardirman. 2010. Interaksi dan Motivasi Belajar Mengajar. Jakarta: Kencana.

[8] Shoimin, A. 2014. 68 Model Pembelajaran Inovatif dalam Kurikulum 2013. Yogyakarta. Ar-Ruzz Media

[9] Trianto. 2010. Mendesaik Model Pembelajaran InovatifProgresif. Jakarta: Kencana.

[10] Waskitoningtyas, R. S. 2016. Analisis Kesulitan Belajar Matematika Siswa Kelas V Sekolah Dasar Kota Balikpapan Pada Materi Satuan Waktu Tahun Ajaran 2015/2016. Jurnal Ilmiah Pendidikan Matematika. 5(1), 24-32.

[11] Rachmah, L. L., Sunyoto, S., \& Sutansi, S. (2017) Peningkatan Hasil Belajar Pkn Materi Lembaga Pemerintahan Pusat Melalui Model Numbered Heads Together di Kelas IV. Wahana Sekolah Dasar, 25(2), $17-$ 23. 